\title{
Competitive Advantages for Attracting FDI in Improving the Business Climate in the Agricultural Sector of the Albanian Economy
}

\author{
Eralda Shore \\ PhD Candidate, "IDEATEL" SHPK coordinator, Tirana, Albania \\ Email: eralda.shore@gmail.com \\ Alvina Coku \\ PhD Candidate, Aleksander Moisiu University, Durres
}

Assoc. Prof. Dr. Edmond Kadiu

Agricultural University of Tirana

Alerta Shtepani

PhD Candidate, Agricultural University of Tirana

Doi:10.5901/mjss.2016.v7n4p

Abstract

Knowing the value of Foreign Direct Investment (FDI) as a mean for encouraging investment, stresses the need for accurate measurements and detailed statistics of FDI for assessing their relationship with economic growth and its impact on various economic sectors, mainly in the agricultural sector. The main purpose is to identify the role, both in terms of increasing the flow of FDI in Albania. An important aspect of the aim of the research is to identify and evaluate the role and impact of FDI in Albanian agriculture, trends and issues or major obstacles to FDI in this sector, focusing in Korca and its municipalities. Over the past decade, the flow of foreign direct investment played an important role in increasing the productivity and efficiency of production, employment and domestic exports. The objectives of this study deal with the analysis of FDI as an important factor for developing countries in terms of globalization of the world economy as well as the direct or indirect impact they have on the Albanian economy with the main focus on agriculture. The business climate is negatively affected by high levels of tax, fiscal instability, unfair competition in the market and the relative insecurity of property rights and lower demand for agricultural products as a result of limited income of the population. In the agricultural sector the business climate is affected negatively by the controversial political stability, perceptions of high level corruption, bad agricultural policies, farm size and its fragmentation, low quality of agricultural inputs, the disapproving trend of collective action and problems with irrigation and drainage infrastructure. The business climate is affected positively, in the medium term, by relatively low standards of food safety, low environmental regulatory norms and the cost of manufacturing resources, mainly land and labor. The research concluded in some general results as follows: The inflow of FDI has contributed positively to employment and economic growth in Albania, but Albania has more spaces for FDI. The inflow of FDI in Albania has contributed to increasing productivity, facilitating access to markets and improvement of the trade balance. The small estate and other structural problems in agriculture are serious obstacles to FDI. These obstacles are expected to be long, hindering the growth of FDI in the long term. Business climate, in particular, fair competition, fiscal facilities and facilities of capital entry and repatriation of profits, safety and property investment, are fundamental factors of the increase of the flow of FDI in Albania. The business climate in Albania has been improving. Agriculture has a competitive advantage in relation to other branches of FDI, but policies are needed to reduce structural barriers, increasing security of property and fiscal facilities.

Keywords: Willingness to Invest, FDI, Agricultural Products, Investment Priority, Strategies of Growth, Business Climate.

\section{Introduction}

In comparison with other regional countries, Albania should use its geographical position and the possibilities of trade relations with other countries in the region and further promoted by the international crossing streets. Some of the suggestions we can give related to the promotion of foreign direct investments in Albania can be linked to reforms to be undertaken in terms of the preservation of macroeconomic stability, the level of prices and the identification of positive 
and negative factors that influence in attracting foreign investment.

The importance of this study at first has to do with a better understanding of the role of FDI in the country's economy in general and agriculture in particular. Further developments in recent years in Albania, which have had a positive impact on the business climate in the country. For years, the business climate in Albania has been improving and growing interest of foreign investors comes and becomes greater, due to macroeconomic stability and implementation of reforms in the country.

In the years 2009-2010, economic growth is attributed a number of factors such as reforms in the economic aspect, credit growth and the role of international institutions in the economic and political aspect of the country and through the financing of various investing projects. Continous improvement of the infrastructure and technology development in different industries of the country and the increasing specialization of labor skills have given their results in economic growth.

Future challenges have to do with creating a climate more favorable to attract FDI in the country, including the construction of new hydropower plants and power plants as well as infrastructure development and agricultural development of water supply,

Korca district is among the biggest districts in the Republic of Albania. It is composed of 6 cities (Korce, Pogradec, Maliq, Erseke, Bilisht, Leskovik), 31 municipalities.

Areas on focus (Maliq, Vithkuq, Bulgarec Drithas, Libonik, Lozhan, Mollas, Pirg, Pojan,).

In our research we have identified the following main specific objectives:

Specific Objective (1): To evaluate the role of FDI committed in Albania in the context of economic development and employment.

The specific objective (2) Assess the obstacles to growth of FDI flow in Albania and ways on how to eliminate or reduce them, in this context, analysis of the business climate and determining ways / roads / actions or conditions that must be fulfilled in order to increase the flow of FDI in the agricultural sector.

The business climate is negatively affected by high levels of tax, fiscal instability, unfair competition in the market and the relative insecurity of property rights and lower demand for agricultural products as a result of limited income of the population.

In the agricultural sector the business climate is affected negatively by the controversial political stability, perceptions of high level corruption, bad agricultural policies, farm size and its fragmentation, low quality of agricultural inputs, the disapproving trend of collective action and problems with irrigation and drainage infrastructure. The business climate is affected positively,in the medium term, by relatively low standards of food safety, low environmental regulatory norms and the cost of manufacturing resources, mainly land and labor.

\section{Material and Methods}

Research methodology is based on interviews / questionnaires. The two main questionnaires l've used are: the questionnaire of farmers and questionnaire survey for specialists, trading, processing businesses.) The first questionnaire reflects the current situation of 150 farmeres of the Korca area. Korca district is among the biggest districts in the Republic of Albania. In its composition there are presented the farmers questionnaires of the following areas (Maliq, Vithkuq, Bulgarec Drithas, Libonik, Lozhan, Mollas, Pirg, Pojan,). The second questionnaire reflects the current situation of 150 specialists, traders, processing businesses of the area of Korca. flows.

We realized panel discussions of experts, to assess barriers, factors and policies in favor of the growth of FDI

Method / comparative analysis to analyze the comparative advantages of the country or sector related to FDI, and to assess rates and differences between countries, regions and sectors in this regard.

We use economic methods to analyze competitive or comparative advantages of the country associated with the products, sectors, prioritized areas for FDI.

To get the expected search results in this work are used econometric models, statistical and e- views programe.

In this research we have formulated some key assumptions:

$\mathrm{H} 1$. The willingness to invest is dependent on the business climate, but the business climate in Albania is not enough incentive for foreign investment, especially in the agricultural sector. (So the willingness to invest is dependent on the business climate.)

$\mathrm{H} 2$. The willingness to invest is in positive relationships with farm size, level of specialization of the farm, the agricultural sub-sector or type of agricultural product to be produced, farm distance from markets and the terrain (plain, hilly or mountainous) 
H3. Higher willingfullness to invest have farms that produce for the market, having more income and receiving technical assistance in a systematic way.

H4. Business climate, in particular fair competition, fiscal facilities and facilities of capital entry and repatriation of profits, safety and property investment, are fundamental factors for the growth of FDI flows even in Albania.

H5. Agriculture has no competitive advantage in relation to other branches of FDI.

\section{Results}

\subsection{The economic situation of the area farms}

\subsubsection{Analyze 2: Refinements for specialists.}

\subsubsection{Current business situation}

\begin{tabular}{|c|ccc|c|}
\hline Count of business situation & \multicolumn{4}{|c|}{} \\
\hline Work & Bad & Satisfactory & Very good & Grand Total \\
\hline Private specialist & 5 & 99 & 2 & 106 \\
Public specialist & & 5 & 1 & 6 \\
Merchant & & 37 & 1 & 38 \\
\hline Grand Total & 5 & 141 & 4 & 150 \\
\hline
\end{tabular}

\subsubsection{Business situation after working for one year}

\begin{tabular}{|c|ccc|c|}
\hline Count of business situation after 1 year & Business situation after working for one year & \multicolumn{4}{|c|}{} \\
\hline Work & Worst & No changes & Better & Grand Total \\
\hline Private specialist & 3 & 62 & 41 & 106 \\
Public specialist & & 6 & 6 \\
Merchant & 3 & 22 & 16 & 38 \\
\hline Grand Total & 3 & 90 & 57 & 150 \\
\hline
\end{tabular}

Most of the respondents believe the situation in business fixed after a year, but a significant number of them thinks that the improvement.

\subsubsection{The current situation in agriculture sector}

\begin{tabular}{|c|ccc|c|}
\hline Count current situation in agriculture sector & Current situation in agriculture sector & \multicolumn{4}{l|}{} \\
\hline Work & Bad & Satisfactory & Very Good & Grand Total \\
\hline Private specialist & 5 & 99 & 2 & 106 \\
Public specialist & & 5 & 1 & 6 \\
Merchant & 5 & 37 & 1 & 38 \\
\hline Grand Total & 5 & 141 & 4 & 150 \\
\hline
\end{tabular}

The current situation in the agriculture sector is deemed satisfactory.

\subsubsection{The situation in agriculture after a year}

\begin{tabular}{|c|ccc|c|}
\hline Count current situation in agriculture sector & Situation in agriculture sector after one year & \multicolumn{3}{|l|}{} \\
\hline Work & Worst & No changes & Better & Grand Total \\
\hline Private specialist & 3 & 56 & 47 & 106 \\
Public specialist & & 6 & 6 \\
Merchant & & 22 & 16 & 38 \\
\hline Grand Total & 3 & 84 & 63 & 150 \\
\hline
\end{tabular}

Most of the respondents believe the situation in agriculture has not changed after one year, but a significant number of them thinks that there was an improvement. 


\subsubsection{Obstacles of agricultural products sale}

\begin{tabular}{|c|c|c|c|c|c|c|c|c|c|c|}
\hline Work & $\mathrm{a}$ & $\mathrm{b}$ & $\mathrm{c}$ & $\mathrm{D}$ & $\mathrm{e}$ & $\mathrm{f}$ & $\mathrm{g}$ & $\mathrm{h}$ & $\mathrm{i}$ & $\mathrm{j}$ \\
\hline Private specialist & 1.19 & 1.15 & 2.60 & 2.48 & 2.53 & 2.77 & 3.02 & 2.86 & 2.69 & 3.37 \\
\hline Public specialist & 2.17 & 1.83 & 3.33 & 2.67 & 3.00 & 3.67 & 4.17 & 4.00 & 3.33 & 3.33 \\
\hline Merchant & 1.45 & 1.47 & 2.74 & 2.26 & 2.13 & 3.05 & 3.05 & 2.97 & 2.47 & 3.39 \\
\hline Grand Total & $\mathbf{1 . 2 9}$ & $\mathbf{1 . 2 6}$ & $\mathbf{2 . 6 7}$ & $\mathbf{2 . 4 3}$ & $\mathbf{2 . 4 5}$ & $\mathbf{2 . 8 8}$ & $\mathbf{3 . 0 7}$ & $\mathbf{2 . 9 3}$ & $\mathbf{2 . 6 6}$ & $\mathbf{3 . 3 7}$ \\
\hline
\end{tabular}

The biggest obstacles of agricultural products sales is considered the unfair competition, the underdevelopment of agroprocessing and storage of the collection system.

\subsubsection{The business climate in agriculture and agro-processing.}

\begin{tabular}{|c|ccc|c|}
\hline Sum of the Impact & Situation & \multicolumn{3}{|c|}{ Grand Total } \\
\hline Work & Not favorable & Less fav & Very favorable & 106 \\
Private specialist & 2 & 51 & 53 & 6 \\
Public specialist & & 6 & 16 & 38 \\
\hline Merchant & & 22 & 69 & 150 \\
\hline
\end{tabular}

Most experts consider the business climate less favorable to agriculture, or rather between little and very favorable

\subsubsection{Factors of willingness to invest}

\begin{tabular}{|c|c|c|c|c|c|c|c|c|c|c|c|c|c|c|c|}
\hline Work & $\mathrm{a}$ & $\mathrm{b}$ & $\mathrm{c}$ & $\mathrm{d}$ & $\mathrm{e}$ & $\mathrm{f}$ & $\mathrm{g}$ & $\mathrm{h}$ & $\mathrm{i}$ & $\mathrm{j}$ & $\mathrm{k}$ & $\mathrm{l}$ & $\mathrm{m}$ & $\mathrm{n}$ & $\mathrm{p}$ \\
\hline Private specialist & 1.07 & 1.10 & 1.42 & 1.59 & 1.45 & 1.80 & 1.03 & 1.44 & 0.98 & 1.42 & 1.92 & 1.45 & 1.60 & 1.65 & 1.58 \\
\hline Public specialist & 0.67 & 0.67 & 1.17 & 1.17 & 0.83 & 0.50 & 0.17 & 0.83 & 0.50 & 0.67 & 1.00 & 0.50 & 0.83 & 1.17 & 1.33 \\
\hline Merchant & 1.00 & 1.18 & 1.21 & 1.26 & 1.37 & 1.32 & 0.61 & 1.08 & 1.03 & 1.05 & 1.45 & 1.08 & 1.32 & 1.32 & 1.34 \\
\hline Grand Total & 1.03 & 1.11 & 1.36 & 1.49 & 1.41 & 1.63 & 0.89 & 1.33 & 0.97 & 1.29 & 1.77 & 1.32 & 1.50 & 1.55 & 1.51 \\
\hline
\end{tabular}

Political environment and the size of the farm are negative factors with regard to the willingness to invest. In general, all factors play a weak role in promoting readiness to invest.

\subsubsection{The directions of improvement in order to stimulate investment}

\begin{tabular}{|c|c|c|c|c|c|c|c|c|c|c|c|c|}
\hline & $\mathrm{a}$ & $\mathrm{b}$ & $\mathrm{c}$ & $\mathrm{d}$ & $\mathrm{e}$ & $\mathrm{f}$ & $\mathrm{g}$ & $\mathrm{H}$ & $\mathrm{i}$ & $\mathrm{j}$ & $\mathrm{k}$ & $\mathrm{I}$ \\
\hline Work & 2.79 & 3.19 & 3.73 & 3.18 & 2.82 & 3.37 & 2.88 & 2.71 & 3.16 & 3.43 & 3.51 & 3.46 \\
\hline Private specialist & 3.17 & 3.67 & 4.00 & 4.00 & 3.67 & 3.67 & 3.83 & 4.50 & 2.83 & 3.83 & 4.00 & 3.67 \\
\hline Public specialist & 3.03 & 3.61 & 4.05 & 3.18 & 2.68 & 3.32 & 2.97 & 2.82 & 3.08 & 3.50 & 3.82 & 3.95 \\
\hline Merchant & 2.87 & 3.31 & 3.82 & 3.21 & 2.82 & 3.37 & 2.94 & 2.81 & 3.13 & 3.47 & 3.61 & 3.59 \\
\hline Grand Total & & & & & & & & & & & & \\
\hline
\end{tabular}

Improvement of banks' loans, reducing informality in business and improving the political environment, lowering taxes, improving irrigation and drainage are considered as the most important factors to promote foreign investment in agriculture.

\subsubsection{Analyzes 3}

The climate and investment according to specialists

\subsubsection{The factors that affects the climate}

Hypotheses: The business climate in agriculture depends positively on irrigation infrastructure and competition in the markets, the level of taxes and the environment and political stability, and current farm size. 
Dependent Variable: The climate

Method: ML - Binary Logit

Sample: 1150

Included observations: 150

Convergence achieved after 4 iterations

Covariance matrix computed using second derivatives

\begin{tabular}{lllll}
\hline \hline Variable & Coefficient & Std. Error & z-Statistic & Prob. \\
\hline \hline C & -3.428832 & 0.556049 & -6.166425 & 0.0000 \\
UJ & 1.082884 & 0.254276 & 4.258686 & 0.0000 \\
Competition & 0.787056 & 0.223082 & 3.528096 & 0.0004 \\
\hline \hline Mean dependent variable & 0.460000 & S.D. dependent variable & 0.500067 \\
S.E. of regression & 0.395419 & Akaike info criterion & 1.001048 \\
Sum squared reside & 22.98440 & Schwarz criterion & 1.061261 \\
Log likelihood & -72.07860 & Hannan-Quinn criteria & 1.025511 \\
Restr. log likelihood & -103.4916 & Avg. log likelihood & -0.480524 \\
LR statistic (2 df) & 62.82592 & McFadden R-squared & 0.303532 \\
Probability(LR stat) & $2.28 \mathrm{E}-14$ & & \\
\hline \hline Obs with Dep=0 & 81 & Total obs & 150 \\
Obs with Dep=1 & 69 & & $=$ \\
\hline \hline
\end{tabular}

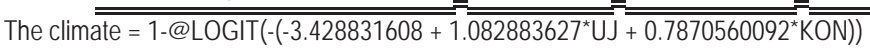

It has been proved that the perception of the business climate is positively related to the perception of the role of irrigation and competition in markets. In other words, if irrigation and improved competitiveness in the markets, it will improve the business climate. By comparison, irrigation is the most important factor.

Dependent Variable: KLIMA

Method: ML - Binary Logit

Sample: 1150

Included observations: 150

Convergence achieved after 3 iterations

Covariance matrix computed using second derivatives

\begin{tabular}{lllll}
\hline \hline Variable & Coefficient & Std. Error & z-Statistic & Prob. \\
\hline \hline C & -2.925726 & 0.609631 & -4.799174 & 0.0000 \\
TAT & 1.271364 & 0.280494 & 4.532587 & 0.0000 \\
MJ POL & 0.799910 & 0.392370 & 2.038660 & 0.0415 \\
\hline \hline Mean dependent var & 0.460000 & S.D. dependent var & 0.500067 \\
S.E. of regression & 0.444663 & Akaike info criterion & 1.200579 \\
Sum squared resid & 29.06565 & Schwarz criterion & 1.260792 \\
Log likelihood & -87.04345 & Hannan-Quinn criter. & 1.225042 \\
Restr. log likelihood & -103.4916 & Avg. log likelihood & -0.580290 \\
LR statistic (2 df) & 32.89623 & McFadden R-squared & 0.158932 \\
Probability(LR stat) & $7.19 \mathrm{E}-08$ & & \\
\hline \hline Obs with Dep=0 & 81 & Total obs & 150 \\
Obs with Dep=1 & 69 & & $=$ \\
\hline \hline
\end{tabular}

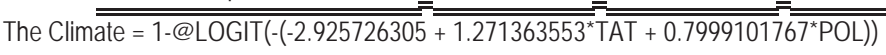

It proved that the perception of the business climate is positively related to the perception of the role of the political environment and the level of taxes. In other words, if these factors improve, it will improve business climate. By comparison, the level of taxes is the most important factor of political environment. 
Dependent Variable: The climate

Method: ML - Binary Logit

Sample: 1150

Included observations: 150

Convergence achieved after 3 iterations

Covariance matrix computed using second derivatives

\begin{tabular}{lllll}
\hline \hline Variable & Coefficient & Std. Error & z-Statistic & Prob. \\
\hline \hline C & -0.731259 & 0.290543 & -2.516872 & 0.0118 \\
FERM & 0.582855 & 0.242308 & 2.405431 & 0.0162 \\
\hline \hline Mean dependent var & 0.460000 & S.D. dependent var & 0.500067 \\
S.E. of regression & 0.491183 & Akaike info criterion & 1.365331 \\
Sum squared resid & 35.70657 & Schwarz criterion & 1.405473 \\
Log likelihood & -100.3998 & Hannan-Quinn criter. & 1.381639 \\
Restr. log likelihood & -103.4916 & Avg. log likelihood & -0.669332 \\
LR statistic (1 df) & 6.183477 & McFadden R-squared & 0.029874 \\
Probability(LR stat) & 0.012895 & & \\
\hline \hline Obs with Dep=0 & 81 & \multicolumn{3}{|c}{ Total obs } \\
Obs with Dep=1 & 69 & & 150 \\
\hline \hline
\end{tabular}

It has been proved that the general assessment for the business climate is positively related to agriculture from current farm size.

\subsubsection{The climate depending on what needs to be improved to encourage foreign investment}

Hypotheses: The improvement of cooperation, stability and political environment and the reduction of tax levels and the informal economy as a factor deemed important for the business climate and encouraging foreign investment in agriculture.

Dependent Variable: The climate

Method: ML - Binary Logit

Sample: 1150

Included observations: 150

Convergence achieved after 3 iterations

Covariance matrix computed using second derivatives

\begin{tabular}{lllll}
\hline \hline Variable & Coefficient & Std. Error & Z-Statistic & Prob. \\
\hline \hline C & 1.683812 & 0.535432 & 3.144772 & 0.0017 \\
KOOP & -0.633966 & 0.176338 & -3.595178 & 0.0003 \\
\hline \hline Mean dependent var & 0.460000 & S.D. dependent var & 0.500067 \\
S.E. of regression & 0.477500 & Akaike info criterion & 1.309761 \\
Sum squared resid & 33.74496 & Schwarz criterion & 1.349903 \\
Log likelihood & -96.23208 & Hannan-Quinn criter. & 1.326069 \\
Restr. log likelihood & -103.4916 & Avg. log likelihood & -0.641547 \\
LR statistic (1 df) & 14.51897 & McFadden R-squared & 0.070146 \\
Probability(LR stat) & 0.000139 & & \\
\hline \hline Obs with Dep=0 & 81 & Total obs & 150 \\
Obs with Dep=1 & 69 & & \\
\hline \hline
\end{tabular}

The climate = 1-@LOGIT(-(1.68381239 - $\overline{\overline{\left.\left.0.6339656993^{*} \mathrm{KOOP}\right)\right)}}=\overline{\overline{\overline{0}}}$

If the business climate is perceived low, the need for improvement in cooperation is great. 
Dependent Variable: The climate

Method: ML - Binary Logit

Sample: 1150

Included observations: 150

Convergence achieved after 4 iterations

Covariance matrix computed using second derivatives

\begin{tabular}{lllll}
\hline \hline Variable & Coefficient & Std. Error & Z-Statistic & Prob. \\
\hline \hline C & 5.493796 & 1.315953 & 4.174765 & 0.0000 \\
MJPOL & -0.499546 & 0.229452 & -2.177123 & 0.0295 \\
TAKS & -0.591961 & 0.233861 & -2.531249 & 0.0114 \\
INFORMAL & -0.509562 & 0.243042 & -2.096595 & 0.0360 \\
\hline \hline Mean dependent var & 0.460000 & S.D. dependent var & 0.500067 \\
S.E. of regression & 0.466061 & Akaike info criterion & 1.268849 \\
Sum squared resid & 31.71302 & Schwarz criterion & 1.349133 \\
Log likelihood & -91.16368 & Hannan-Quinn criter. & 1.301466 \\
Restr. log likelihood & -103.4916 & Avg. log likelihood & -0.607758 \\
LR statistic (3 df) & 24.65577 & McFadden R-squared & 0.119120 \\
Probability(LR stat) & $1.82 E-05$ & & & 150 \\
\hline \hline Obs with Dep=0 & 81 & Total obs & $=$ \\
Obs with Dep=1 & 69 & $=$ & $=$ \\
\hline \hline
\end{tabular}

The improvement of the political environment, the reduction of informality and taxes of those who want more of quoting lower business climate; or if the business climate is perceived low, the need for improvement in these areas is huge. $\mathrm{J}$ negative coefficients indicate how close lower is the business climate, the greater is the need for improvements in these areas. The need to reduce taxes somewhat greater feels the need to improve the informality and political environment, whether to improve the business climate.

\section{Conclusions and Recomandations}

According to the data processing, we could conclude that the inflow of FDI has contributed positively to employment and economic growth in Albania, but Albania has more space for FDI.

- The inflow of FDI in Albania has contributed to increasing productivity, facilitating access to markets and improve the trade balance.

- Small property and other structural problems in agriculture are serious obstacles to FDI. These obstacles are expected to be long, hindering the growth of FDI in the long term.

- The study conducted showed that the business climate, in particular, fair competition, fiscal facilities and facilities at the entrance of capital and repatriation of profits, security of investments and property, are important factors for increasing the flow of FDI also in Albania. The business climate in Albania has been improved.

- Agriculture has the competitive advantage in relation to other branches of FDI, but policies are needed to reduce structural barriers, increasing security of property and fiscal facilities (since these factors mare in the study emerged that impact and are important).

\section{Questionnaires Results}

According to the data processing, we could conclude that:

- The business climate in agriculture depends on irrigation positively infrastructure and competition in the markets, the level of taxes and the environment and political stability, as well as the actual size of the farm.

- The improvement of cooperation, stability and political environment, the reduction of taxes and the informal economy is an important factor thought the business climate and encouraging foreign investment in the agriculture sector. 
- Improving the political environment, the elimination of informality and reducing taxes and require more who sits quoting business climate; or if the business climate is perceived low, the need for improvement in these areas is huge. (J) Negative coefficients indicate how close lower business climate, the greater is the need for improvements in these areas.

- $\quad$ The need to reduce taxes feels somewhat greater need for improving the informality and political environment to be improved if the business climate.

Based on the responses to the survey, the results show that:

Most of the respondents (69 of them) believe the situation in business fixed after a year, but a significant number of 77 of them thinks that the larger improvement. The obstacles of agricultural products sale are considered unfair competition, poor agro-processing development and storage.

Most experts consider the business climate less favorable to agriculture, or rather between little and very favorable.

The political environment and the size of the farm are more negative factors about the willingness to invest. In general, all factors play a stronger role in promoting the readiness to invest.

The banks' loans improvement, the reduction of business informality and improvement of the policy environment, the reduction of taxes, improvement of irrigation and drainage, considered as the most important factors to promote foreign investment in the agricultural sector. Willingness to invest in the production of fruit depends on gender and type of farm, the farmer's age, distance from the market and the perception of the current state of the business climate, and the amount of land owned.

The current situation in agriculture in the region of Korca is satisfactory but there is room for improvement.

\section{References}

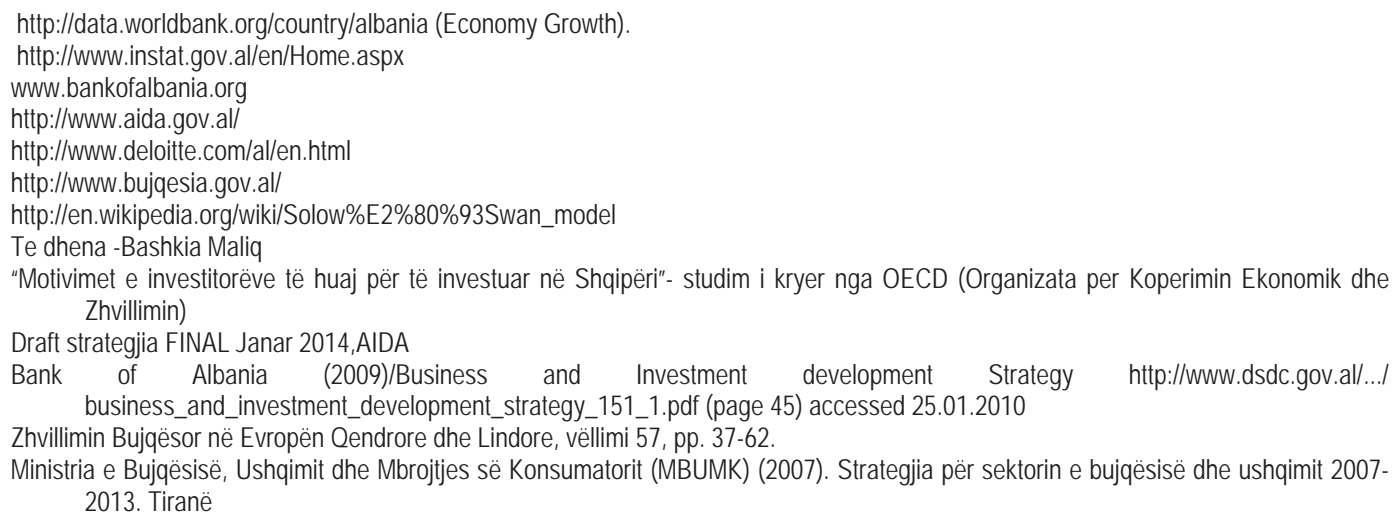

